\title{
Participatory Resource Mapping for Livelihood Values Derived from the Forest in Ekondo-Titi Subregion, Cameroon: A Gender Analysis
}

\author{
Daniel B. Etongo ${ }^{1}$ and Edinam K. Glover ${ }^{2}$ \\ ${ }^{1}$ Department of Forest Sciences, Viikki Tropical Resources Institute (VITRI), University of Helsinki, P.O. Box 27, \\ 00014 Helsinki, Finland \\ ${ }^{2}$ Faculty of Law, University of Helsinki, P.O. Box 4, 00014 Helsinki, Finland
}

Correspondence should be addressed to Daniel B. Etongo, daniel.etongobau@helsinki.fi

Received 3 September 2011; Revised 15 December 2011; Accepted 27 December 2011

Academic Editor: John Sessions

Copyright ( 2012 D. B. Etongo and E. K. Glover. This is an open access article distributed under the Creative Commons Attribution License, which permits unrestricted use, distribution, and reproduction in any medium, provided the original work is properly cited.

\begin{abstract}
Increasingly, the multiplicity of products, services, and values, and the diversity of interests from different resource users and groups, is being acknowledged as vital for sustainable use. This calls for a shift from protection to sustainable use and to resourceuser focus. The aim of this study is to identify the spatial occurrence of livelihood values through participatory resource mapping, their changes over time and alternatives for sustainable management. A participatory resource mapping study was conducted with local community, including important stakeholders in Ekondo-Titi subregion of Cameroon. The research technique which focused on gender revealed different patterns of forest resources and changes on the landscape. The study concludes that the importance of resources varies between men and women in Ekondo-Titi subregion of Cameroon, implying that resources may have multipurpose functions, but its exact role depends on the needs of the user groups that utilize them. The divergence of opinion on certain resources is a clear indication of preferences that are gender motivated. The study also revealed that the greatest impact of land use change is the conversion of forest land into agriculture.
\end{abstract}

\section{Introduction}

The forest ecosystem just like other ecosystem provides humanity with a wide range of resources and services which are necessary for our survival. These services have been categorized as provisioning, regulating, cultural, and supporting services which interact with the direct and indirect drivers of change to affect human well-being [1-4]. Though there is much awareness as to the potentials of the forest ecosystem, having a match between policies and practice is the root cause of poor management of resources. This erodes the capacity of the forest to provide necessary services not only to the local community but the nation as a whole [5-10].

Much of the debate on how to conserve forest resources while protecting biodiversity and meeting the demands for community development at the same time has been very challenging $[11,12]$. This is because conservation initiatives have often been limited to a protected area of which that is not the case in reality because there is the need for conservation for development and not the other way round [13]. Those who advocate for conservation, designating parks under strict protection often accuse the local communities as threat to biodiversity conservation $[4,11,14,15]$. Such an approach towards conservation explains why most conservation projects in West Africa have failed in the past [16]. The local population is aware and well connected with their surrounding landscapes thus being the best suited for shaping the future of their landscapes and contributing meaningfully towards a successful management plan $[12,17]$.

The emphasis on a participatory approach arises from the wisdom that local communities not only understood their problems best but also had solutions. This made them be able to participate as beneficiaries and also as providers $[18,19]$. Within the natural resource sector, the 
participatory approach argument became a focal point and attracted a great deal of attention, following the Rio Earth Summit, where it was accepted as an integral part of the sustainable development process [20]. By involving all key stakeholders in the process of resource management, understanding their needs and situations, allowing them to influence decisions and receive benefits, and increasing transparency [21], participatory research will go a long way to secure local promote sustainable resource management $[22,23]$. Conservation and development have often been addressed as separate issues which are not the case in reality because a balance must be established to achieve both objectives $[15,24]$. Building upon indigenous knowledge is no longer an option but imperative for sustainabl resource management [25]. The active involvement of the indigenous knowledge holders in the decision-making process in as far as it affects them reinforces indigenous knowledge systems for sustainable natural resource management and local livelihoods [17]. Stakeholders are involved in a joint participation in which they share their problems and also share the benefits [26]. Collective analysis of problems will stimulate that sense of belonging which will contribute to sensitivity of the local community and also create collaboration in resource planning as power is shared among stakeholders [22].

Participatory rural appraisal (PRA) has emerged as a new approach that is invaluable to community development planning and resource management. This practice advocates for sustainable resource management through the active participation of local communities with the aim of improving livelihood, empowerment (access rights and security), and enhancing environmental conservation [2729]. PRA is multidisciplinary and multidimensional in its approach and has gained attention in almost all fields of studies be it the humanities, sciences, arts, social sciences, health, and so forth [30, 31]. PRA has moved from a more general to specific levels that focus on issues such as gender, ethnic diversity, age groups, and structure. Communities are not homogenous but rather heterogeneous in nature [32] which creates problems for resource management as different ethnic groups have different cultural values that affect access and control rights to forest resources [33-35].

Hardin [37] puts forward the following views that "the users of a commons were trapped in inexorable tragedy and unable to engage in sufficient collective action to extract themselves from drastic overuse and destruction". This view has received a lot criticism from scholars since the 80s [3841] on the grounds that it is too general and some local examples have proven otherwise. Notwithstanding these criticisms, Hardin's view still holds true in some regions where resource management has not been sustainable. It has been estimated that approximately 200,000 ha of forests are being lost to agriculture each year in Cameroon [42]. Other studies give similar estimates which reveals that in a ten-year-period (1990-2000) in Cameroon, forest loss to other land uses per annum was approximately 221,763 ha [43]. Devolution of forest rights will have an effect on access and users right which will improve on forest management approaches and local livelihoods $[44,45]$.
The aim of this study was to conduct a participatory resource mapping exercise with the local community of Ekondo-Titi in attempts to identify and locate the different forest resources and uses in the area. Participatory Resource Mapping (PRM) is a tool used by practitioners of participatory methods to obtain a systematic and graphic [46] overview [17] and understanding [46] of the resources available with the community in the form of social, economical, demographical, and geographical details of the area where the community lives $[17,47,48]$. The aim of the mapping exercise with the villagers was to produce a resource map of the present situation and the situation in the past on a landscape level. The issue of gender was of greater concern to evaluate the different ways men and women can appreciate their resources on a landscape level. The investigators choose this method because of its many advantages (e.g., [19, 46, 4851]). One argument is that the PRM tool serves as the base for discussions for the entire group of villagers. It also serves to elucidate important points and helps to verify and check the accuracy and validity of information gathered from household questionnaire, key informants' interview, and literature review [17].

Another argument rests on the justification that participatory methods and approaches with local people who utilize the resources on a daily basis, who are knowledgeable about its constraints and limits, its diversity and its opportunities, can increasingly be a practical and effective means of obtaining and managing people-centred natural resources management data [46]. Chambers enumerated wide range of uses of PRM: uses include land use and resource planning and management, wildlife conservation, identifying tenure and rights, negotiating boundaries and resources uses, resolving conflicts, and participatory monitoring and evaluation.

\section{Study Site and Methods}

2.1. Study Site. Ekondo-Titi subdivision consists of thirtyfour villages and one urban center which are all located in Ndian division in the South West province of Cameroon. This area was carved out from the Kumba division in 1966 by presidential decree No. 66/08/66. It is bounded by Mundemba to the north, to the west by the rural district of Kumbo Etindi, to the south by Bamusso subdivision, and to the east by Meme division (Figure 1). It is situated in the equatorial rainforest zone of Cameroon and experiences both the rainy and dry season. This area is characterized by lowlands of vast extent with fairly undulating hills that rises to the Rumpi range of mountains with the highest peak at the Rata Mountain in Dikome Balue $(1900 \mathrm{~m})$. The high lands of this region are located between latitudes $4^{\circ}$ and $7^{\circ}$ north of the equator. The estimated population of this region is 55,000 people distributed over a surface area of $5.602 \mathrm{~km}^{2}$ and projected at 100,000 people by 2015 [36].

The geology of the area shows precambrian basement gneisses overlain unconformably by cretaceous shaly sandstones. Volcanic extrusions are said to have formed the Rumpi range of Mountains that constitutes a series of plateaus separated by gorges and narrow valleys [52]. The 


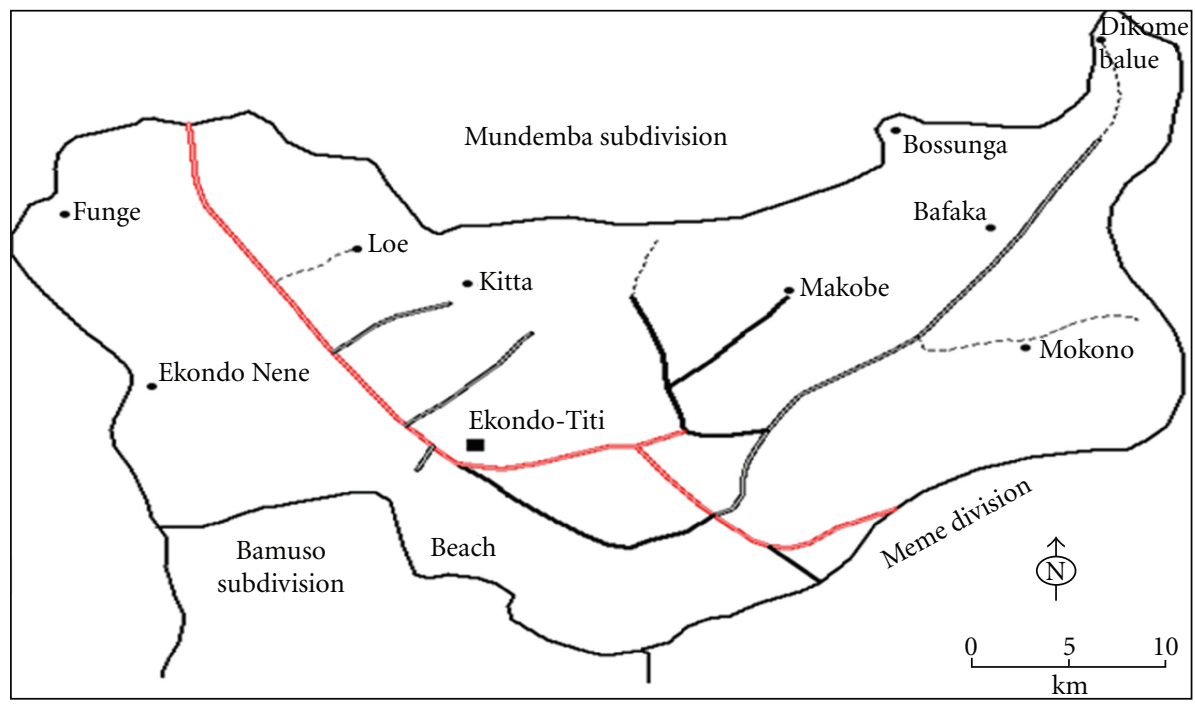

FIgURe 1: Administrative map of Ekondo-Titi sub-Region [36].

soil types that dominate this region are sandy and clay soils. Clay soils have developed from the volcanic ashes that were deposited during periods of active sequence of volcanic eruptions that took place in the past [53].

Located in the equatorial forest zone of Cameroon, this area is very rich in floristic composition with varieties of plant species that range from simple fungi to complex angiosperms found in the terrestrial ecosystem. Notwithstanding, significant variation do occur in the distribution of the forest ecosystems in this area which is a true reflection in the changing agricultural landscape. Oil palm plantation forms a new vegetation type though there are tree species such as Rhizophora racemosa, Nypa frauticans, Guibourtia demensei Acrostidum aureum, Hibiscus tiliaceus, Guibourtia demensei, Drepanocarpus lunatus, Pandanus candelabrum, and Phoenix reclinata $[5,54]$.

Subsistence food cultivation is the main source of livelihood to approximately $85 \%$ of the population in 33 out of the 36 villages in the study area. Food crops such as cassava, yams, cocoa yams, maize, groundnuts, plantains, vegetables, and other spices are cultivated extensively in this area. The collection of nontimber forest products (NTFPs) is also widely practiced in this area which is considered as an offseason job when pressure on crop cultivation is reduced. Some of the villagers are employed as labourers by Pamol Plantations Plc (PPP) which is the second largest employer after the government in the South West region of Cameroon. Locally made craft with NTFPs from the forest such as loose fruit baskets are of high demand by PPP and other common initiative groups (CIG) that are involved in oil palm cultivation.

\subsection{Methodology}

2.2.1. Participatory Resource Mapping with Men and Women. Participatory resource approach in form of participatory resource mapping was employed in collecting information.
The period of data collection was in the month of June to August 2009 [55] and the month of December 2010 in which the mapping exercise was conducted with both men and women from the local communities in this region. The mapping exercise was conducted in two phases: at the landscape level which was for the whole region (this was done by a member of the Ekondo-titi traditional council) and at the village level. The villages considered for the mapping exercise were Ekondo-Titi and Bafaka Balue that are located in the center and north-east of the region. The reasons for selecting the above villages are that, Ekondo-Titi is located on gentle undulating land with high population density, cultural diversity and surrounded by oil palm plantations. Bafaka on the other hand, is mountainous, dominated by indigenous population and the physical environment has favored the creation of protected areas (site with the highest biodiversity in the study area), it is the main water catchment of the region and supplies food crops to the former and other villages. In Ekondo-Titi, 10 men and 8 women were involved in the mapping exercise while in Bafaka Balue, 8 men and 6 women were involved.

During the mapping exercise that lasted for 2-3 hours, the participants were given a brief lecture about what is required of them in this exercise. Samples of related works such as Glover, "Tropical dryland rehabilitation: case study on participatory forest management in Gedaref," Sudan and Kalibo and Medley, "Participatory resource mapping for adaptive collaborative management at Mt. Kasigau, Kenya" $[17,19]$ provided a guide for the subject matter. The villagers were given the opportunity to construct a resource map on the open ground using local materials such as stones, leaves, and back of trees. After this phase, the participants were given a cardboard paper with pencils and erasers to transfer the map drown on the ground. They were later given a hundred seeds each per group (men and women's group) to place on the cardboard where they obtain water, where they practice agriculture, where they collect forest products such as fish, 
bush meat, building materials, and fuel wood. The maps were later recopied on an A4 paper by the investigators, scanned and reduced for better presentation.

Field visit was also carried out in some villages such as Masore, Lobe, and Lipenja that are located at the outskirts of Ekondo-Titi village. During such visit that received a lot of support from forestry and agricultural extension workers, some photographs were taken and farmers were able to express their views in terms of resource management in the area.

2.2.2. Historical Resource Mapping and Analyses. This exercise was conducted with the help of 15 men drawn from the Ekondo-Titi traditional council, including the paramount chief for the whole region. This council is madeup of men only but with a brief discussion the investigators had with the paramount chief, three women were asked to join the mapping exercise. The three women that were included just like the members of the traditional council were all indigenous and have lived in this village for all their lives (the youngest amongst them was 62 years old).

This exercise was able to produce two historical maps that covered the period 1940-1960 and 1960-1980. The three women gave valuable contributions since they have more access to the forest especially for fuel wood collection and food crop cultivation. Questions such as where was the first settlement in this region and why? What were sites for different forest products? Have the sites changed? What about the water resources? where questions were asked. The elders were asked of some of the significant events that have taken place with much impact on the landscape and also how the availability of resources has changed.

\section{Results and Discussions}

3.1. Participatory Resource Mapping with Men and Women in Ekondo-Titi Village. The mapping of resources concentrated on two villages in which men and women mapped their resources based on the values attached to them and also by using their local knowledge (Figure 2: Ekondo-Titi village and Figure 3: Bafaka village). In the case of Ekondo-Titi, both men and women mapped a narrow forest zone to the north. The difference in the women's map is that the forest covers the boundary of the entire village except a narrow strip of land towards the north-west which is considered as oil palm plantations (Figure 2(a)). The women also indicated the sites for fuelwood collection which is given a higher value by women since it is considered as a woman's duty to collect wood for the household. Areas of subsistence crop cultivation were identified close to the homes and major roads while agroforestry is said to be fast developing towards the south due to land scarcity. Both men and women identified almost similar area occupied Pamol Plantations with its oil palm plantations but the women went further to identify the buffer zones of the company which they use for food crop cultivations. The women view the landscape to be more expanded in terms of the resources that it provides. They went further to identify the areas very close to the river that is used all-year-round for vegetable cultivation. The women did not consider the rivers just for fishing but as a means of transport of fuelwood from the mangrove forest.

A study by Glover [17] incorporated this finding that the importance of various functions of natural resources may vary between different user groups. This study also found in Elrawashda area in the Sudan that women were more interested in the role of trees for domestic fuelwood supply or food production while men regard commercial gum arabic production as major role of trees. Related works by Campbell [56]; Dei [57]; Falconer [58]; Rocheleau [59]; Nabanoga; Gombya-Sembajjwe [60] and Mogaka et al. [61] also found that trees and forests in subsaharan Africa constitute a major source of income and livelihoods. A study by Kaimowitz [62] found that losing access to these forest products and markets can have negative impacts on rural households and even threaten their survival. Other studies recorded by FAO [63] found out that focusing on one aspect of forest products and benefits, even on such a major one as fuelwood, at the expense of others can be gravely misleading. Trees are considered a major source of support for rural community at the times of vulnerability; therefore, analysis of the main causes of depletion of the forest resources must be based on these needs of rural communities. Extension programmes may bring men who perceive rivers as a source of only one benefit towards accepting the rivers for more than one benefit and towards believing that the river is for multiple uses. The more the people perceive resources (also trees and forests) as for multiple uses, the better can be the acceptance of a multiple land use system [17].

While the women considered the homes and resources to be concentrated in smaller areas, the men on the other hand considered it to be more expanded (Figure 2(b)). Women were interested in resources such as water for domestic use, fuelwood, home garden, and fruit trees. The concentration of these resources by the women is to reduce travel time but culture plays a major role. Cash crop cultivation and hunting of games are considered as activities for men according to the tradition and customs of the land. This explains some of the reasons why the men had an extended view of resources on the landscape when compared with the women. The men were able to locate their cocoa farms and hunting sites which are considered as men's job. In the men's map, the water catchment sites were identified while the agroforestry farms were located to the south, west, and center. The men paid little attention to areas used for food crop but more to cash crops and agroforestry (trees on farms). According to the men building materials came from the north and western part of the village and that the forest to southen west was the major supplier until the 80 s.

When Cameroon gained her independence in 1960, resource exploitation took a different dimension as the forest was seen as the only mean to consolidate the fragile state. The number of villages increased from 6 to 36 while the area under agriculture continued to increase. The presentday Ekondo-Titi region is dominated by oil palm plantation while subsistence agriculture, relying on slash-and-burn also brought about some changes in the forest ecosystem (Figure 5). The slash-and-burn agriculture coupled with oil 


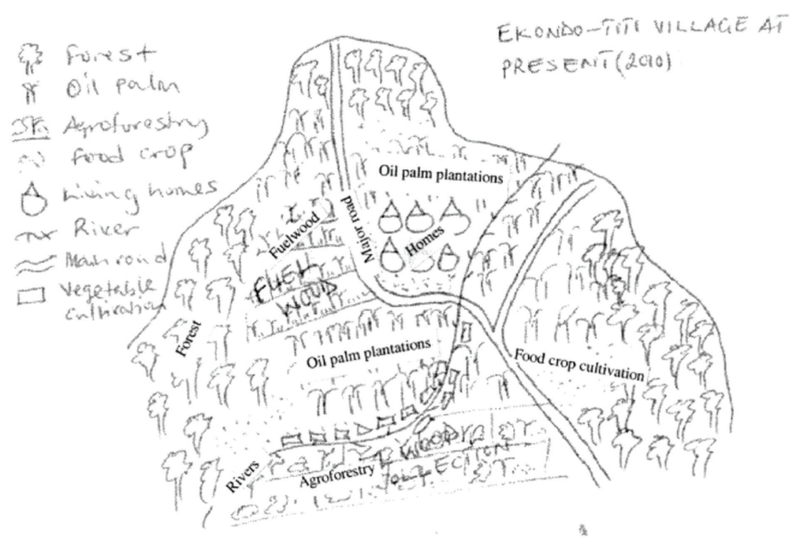

(a)

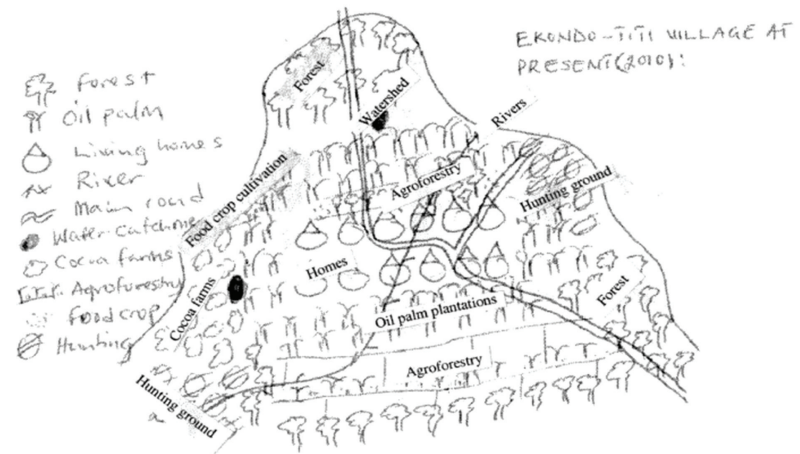

(b)

Figure 2: (a) Participatory resource maps of the present landscape drawn by women of Ekondo-Titi village showing the arrangement of the various resources in the area. (b) Participatory resource maps of the present landscape drawn by men of Ekondo-Titi village showing the arrangement of the various resources in the area.

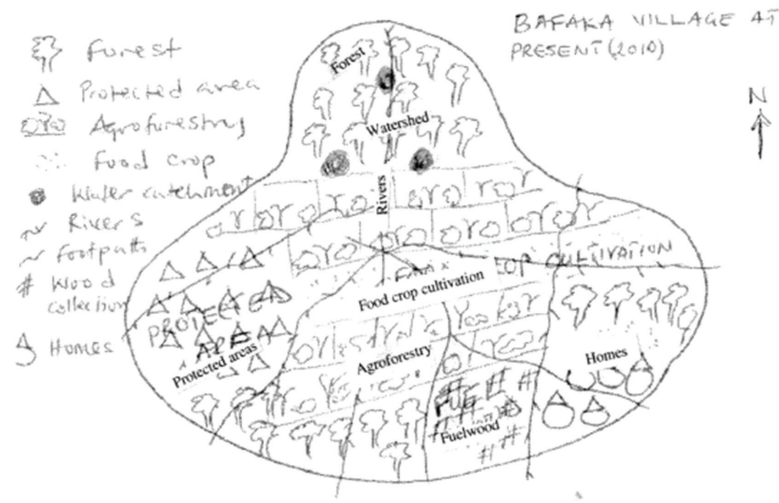

(a)

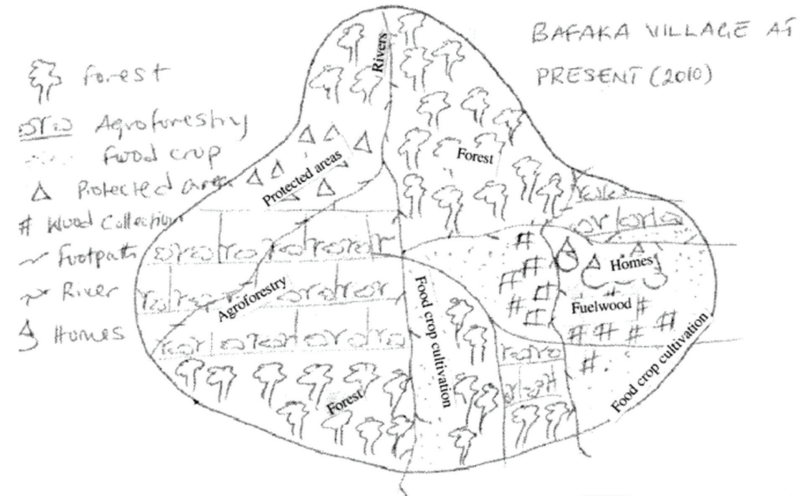

(b)

FIGURE 3: (a) Participatory resource map of the present landscape drawn by men of Bafaka showing the arrangement of the various resources in the area. (b) Participatory resource map of the present landscape drawn by women of Bafaka showing the arrangement of the various resources in the area.

palm plantations has resulted in a number of environmental impacts such as fast conversion of the forest lands in this region to grasslands. This situation has resulted in the loss of livelihoods for local people and the deterioration of the environment in which they live. There is need to find alternatives to monocultural plantations that reflect more environmentally friendly approaches to land use patterns in the region [64].

\subsection{Participatory Resource Mapping with Men and Women} in Bafaka Village. The situation in Bafaka (Figures 3(a) and 3 (b)) portrays a different situation because this area is mountainous and highly inaccessible until 1995 when a secondary road was constructed by the government. This situation explains why the influence of oil palm plantation that dominates this region is not favorable in this area because of the topography. The men's map identified the homes to the south east which is similar to that of the women with much of the forest still intact in the north, west, and south. According to Figure 3(a), the center is dominated by agroforestry with a mixture of cocoa, cocoyam, plantains, banana, maize, and cassava. The south-west is the protected area under the Rumpi Hills conservation project while the rivers take their rise from the Rata Mountain in the north and flow over the entire village and the region as a whole. Hunting, fishing, and the collection of nontimber forest products such as medicinal plants, fruits, and thatches for building are dominated but not restricted to men.

The women were able to identify similar features just as the men but more attention was given to sites for fuelwood collection and food crop cultivation. The major difference in these maps is that, the area identified as protected areas by men (Figure 3(a)) was identified as agroforestry farms by the women (Figure 3(b)). The women gave the protected area a restricted range to the east while food crop cultivation was located to the center, south, and south east. In tropical 


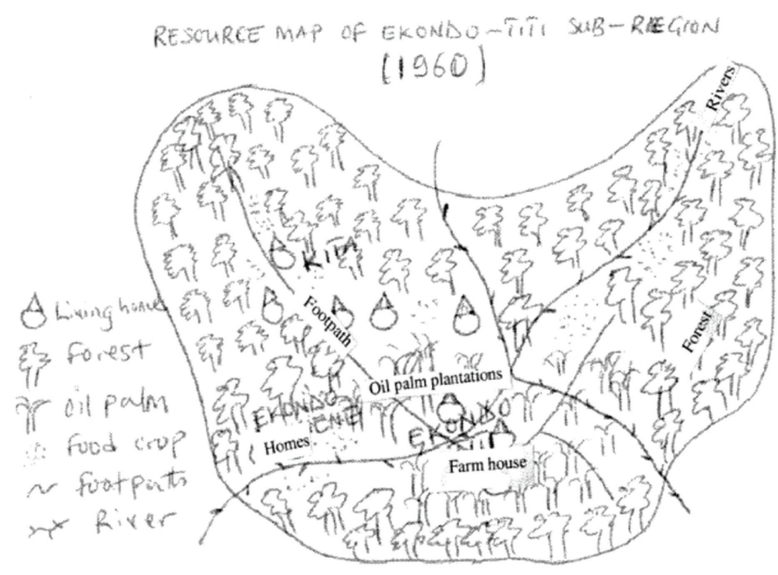

(a)

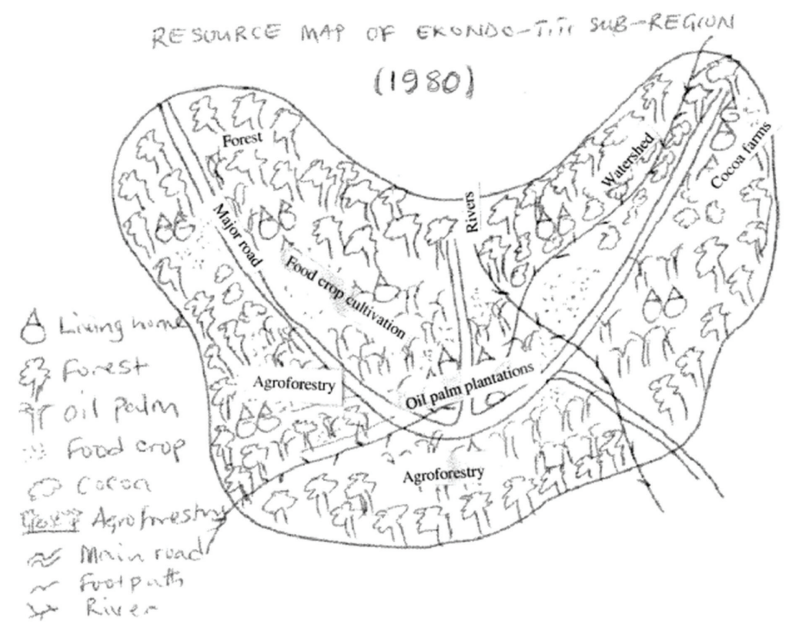

(b)

FIgURE 4: (a) Historical map of the past landscape showing the Ekondo-Titi region between 1940-1960. (b) Historical map of the past landscape showing the Ekondo-Titi region between 1960-1980. The maps (a) and (b) were drawn by members of the Ekondo-Titi traditional council with contributions from three elderly women in the village.

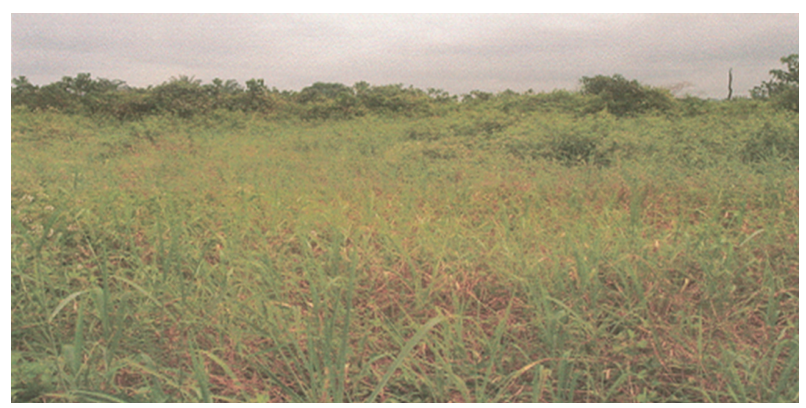

Figure 5: Forest ecosystems are converted to savannah due to frequent use of fire along the Ekondo-titi-Mundemba major road.

forest areas, people normally apply specific practices for utilization and management of forest and/or trees [65]. In the study area, women are responsible for collecting firewood and fruits, but men own property and are in charge of agricultural production.

Men in both villages are unlike women who were more concerned with food crops, fuelwood, water, and so forth, the men were concerned with the forest (hunting of games and collecting NTFPs), cash crops, and building materials from the forest. In Ekondo-Titi the men consider the trees on farm in agroforestry system as fodder for animals. The situation in Bafaka tells a different story as both men and women consider agroforestry as an adaptation to the difficult environment. Wiersum [66] incorporated the above facts and confirmed recognition of gender issues as an important aspect in resource management and implications for planning of interventions in resource use. It should be recognized that the inclusion of both men and women is vital in analyzing the feasibility of a social forestry intervention in a specific situation, in order to be able to assess the dynamic factors that determine the existing divisions of labor, decision making, the allocation of profits and incentives and the potential for change in these dynamics [Ibid.]. Similar findings have been reported by Seniloli et al. [67], regarding gender differences in patterns of resource use. They observed that lack of adequate knowledge or consideration with regard to gender issues can hamper development efforts. The foregoing statements have confirmed that involving gender issues in environmental programmes and the various ways in which men and women utilize their natural resources is crucial if development programmes are to be relevant and sustainable. Thus, formulating policy or project interventions from a gender perspective coupled with collaborative resource management; "a partnership by which various stakeholders agree on sharing among themselves the management functions, rights and responsibilities for a territory or a set of resources" [68], have implications in environmental and poverty reduction strategies and imperative for sustainable resources management.

3.3. Changes in the Landscape Over Time (1940-1960 and 1960-1980). According to the members of the Ekondo-Titi traditional council, the very first settlers in this region were in Ekondo-nene which lies approximately $25 \mathrm{~km}$ away from Ekondo-Titi. Figure 4 shows the historical maps of the past landscape of the Ekondo-Titi subregion between 1940-1960 (a) and 1960-1980 (b). When the Germans established the banana plantation in the 1920s in Lobe, job opportunities were available to the people of Ekondo-nene as labourers in the plantation. The banana plantation was later replaced with oil palm (Elaeis guineensis) plantation by 1930. Ekondo-Titi which literally means "small ekondo" started as a dormitory village. This was due to its suitable location which was closer to the road and closer to the plantation in Lobe $(2.5 \mathrm{~km})$ Ekondo-nene on the otherhand, which means "big ekondo" gave birth to the former due to its distance from the 
plantation site in Lobe $(27.5 \mathrm{~km})$. The forest was still intact with footpaths being the main means of transportation since the crops were transported through the sea to the present-day economic capital of the country, Douala. The council reveals that streams and rivers were flowing across the village and wildlife was abundant. Most people depended on the forest and collected NTFPs from the forest with the authority of the traditional ruler. When the secondary road was constructed in the 1960s, the forest began to disappear and oil palm plantation was dominating as a form of land security to the indigenous from outsiders. The council stated that is the reason why almost all the native own hectares of oil palm plantations because the seedlings were available and at a cheaper rate.

\section{Conclusion}

The understanding of resource diversity, their values, and distribution within a community is best known through participatory research and mapping of resources within the landscape. Though the concept of landscape can be considered from different view points, this study considered the distribution of forest resources and other ecosystem services in the whole region with reference to two local examples for better understanding. The findings of this study focus on how men and women give preferences to different resources use and how they consider the distribution of such resources within the community. While the women valued their lands for food crop cultivation, sites in the forest for fuelwood collection, men on the other hand paid more attention to cash crops such as oil palm and cocoa plantation, forest reserves where they hunt games, and forest area for building materials and the rivers for fishing. Considering the various ways in which men and women utilise their natural resources, collaborative resource management has implications for the planning of interventions in environmental and poverty reduction strategies, if rural development programmes are to be relevant and sustainable.

The historical map of the region which was drawn by members of the traditional council reveals a number of changes that has taken place in the past. While the council stated that the region was a forest area with little evidence of cash crop cultivation in the colonial administration. They described the present-day Ekondo-Titi villages, Lobe, Masore, Bogongo 1 and 2, Bekora, and Lipenja villages as "palm cities." This is a clear indication that the greatest impact of land use change has been agriculture especially through the cultivation of oil palm which remains a constant reminder of a colonial inheritance in this region and other parts of the country and Africa as a whole.

The participants in Ekondo-Titi village show in both the men's and women's map that oil palm plantations are dominating the landscape which has limited the land available for food crop cultivation. Subsistence farming was identified very close to the roads, in agroforestry systems and even in buffer zones. The participatory mapping also reveals that a greater proportion of fuelwood used in Ekondo-Titi village is harvested from the mangrove forest in the maretime region and from neighbouring villages. The participants also complaint that the forest policies by the Ministry of Forestry and Wildlife donot meet the demands of the local communities. Resource management must always take a community-based approach if it has to succeed which must also take into account conservation and development objectives. We therefore recommend that this region should design its own resource map based on local knowledge on how the community perceives its resources can be managed. This is because the landscape is changing all the time and a human-resource relation that is flexible which involves cooperation of the government with the local communities will cope with the changing landscape.

\section{References}

[1] R. Costanza, R. D'Arge, R. De Groot et al., "The value of the world's ecosystem services and natural capital," Ecological Economics, vol. 25, pp. 3-15, 1998.

[2] Millenium Ecosystem Assessment, Ecosystem and Human Well-Being, Island Press, Washington, DC, USA, 2003.

[3] C. Kremen, "Managing ecosystem services: what do we need to know about their ecology?" Ecology Letters, vol. 8, no. 5, pp. 468-479, 2005.

[4] P. Balvanera, G. C. Daily, P. R. Ehrlich et al., "Conserving biodiversity and ecosystem services," Science, vol. 291, no. 5511, pp. 2035-2262, 2001.

[5] E. N. Ndenecho, Biological Resource Exploitation in Cameroon: From Crisis to Sustainable Management, Unique Printers, Bamenda, Cameroon, 2005.

[6] G. C. Daily, Nature's Services: Societal Dependence on Natural Ecosystems, Island Press, Washington, DC, USA, 1997.

[7] A. Balmford, R. E. Green, and M. Jenkins, "Measuring the changing state of nature," Trends in Ecology and Evolution, vol. 18, no. 7, pp. 326-330, 2003.

[8] G. W. Luck, G. C. Daily, and P. R. Ehrlich, "Population diversity and ecosystem services," Trends in Ecology and Evolution, vol. 18, no. 7, pp. 331-336, 2003.

[9] M. Palmer, E. Bernhardt, E. Chornesky et al., "Ecology for a crowded planet," Science, vol. 304, no. 5675, pp. 1251-1252, 2004.

[10] G. P. Robertson and S. M. Swinton, "Reconciling agricultural productivity and environmental integrity: a grand challenge for agriculture," Frontiers in Ecology and the Environment, vol. 3, no. 1, pp. 38-46, 2005.

[11] J. Hutton, W. M. Adams, and J. C. Murombedzi, "Back to the barriers? Changing narratives in biodiversity conservation," Forum for Development Studies, vol. 32, no. 2, pp. 341-370, 2005.

[12] P. R. Wilshusen, S. R. Brechin, C. L. Fortwangler, and P. C. West, "Conservation and development at the turn of the twenty-first century," in Contested Nature: Promoting International Biodiversity with Social Justice in the Twenty-first Century, S. R. Brechin and P. R. Wilshusen, Eds., 2003.

[13] D. Western and M. Wright, "Background to communitybased conservation," in Natural Connections: Perspectives in Community-Based Conservation, D. Western, M. Wright, and S. Strum, Eds., Island Press, Washington, DC, USA, 1994.

[14] J. I. O. Abbot, D. H. L. Thomas, A. A. Gardner, S. E. Neba, and M. W. Khen, "Understanding the links between conservation and development in the Bamenda Highlands, Cameroon," World Development, vol. 29, no. 7, pp. 1115-1136, 2001. 
[15] P. Mbile, M. Vabi, M. Meboka et al., "Linking management and livelihood in environmental conservation: case of the Korup National Park Cameroon," Journal of Environmental Management, vol. 76, no. 1, pp. 1-13, 2005.

[16] J. F. Oates, Myth and Reality in the Rain Forest: How Conservation Strategies Are Failing in West Africa, University of California Press, Berkeley, Calif, USA, 1999.

[17] E. K. Glover, "Tropical dryland rehabilitation: case study on participatory forest management in Gedaref, Sudan," Tropical Forestry Reports 27, Viikki Tropical Resources Institute, University of Helsinki, Finland, 2005.

[18] M. Sekher, "Organized participatory resource management: insights from community forestry practices in India," Forest Policy and Economics, vol. 3, no. 3-4, pp. 137-154, 2001.

[19] H. W. Kalibo and K. E. Medley, "Participatory resource mapping for adaptive collaborative management at Mt. Kasigau, Kenya," Landscape and Urban Planning, vol. 82, no. 3, pp. 145158, 2007.

[20] D. Kelly, "Community participation in rangeland management. A Report for the Rural Industries Research and Development corporation (RIRDC)," RIRDC Publication No. 01/118;RIRDC Project No. QDL-2A, RIRDC, Australia, 2001.

[21] "Forestry, forest users and research: new ways of learning," in Proceedings of the Learning from Resource Users: A Paradigm Shift in Tropical Forestry, A. Lawrence, Ed., p. 190, ETFRN, Vienna, Austria, 2000.

[22] N. L. Johnson, N. Lilja, J. A. Ashby, and J. A. Garcia, "The practice of participatory research and gender analysis in natural resource management," Natural Resources Forum, vol. 28, no. 3, pp. 189-200, 2004.

[23] D. Mosse, "People's knowledge, participation and patronage: operations and representations in rural development," in Participation: The New Tyranny? B. Cooke and U. Kothari, Eds., Zed Books, New York, NY, USA, 2001.

[24] D. Armitage, "Adaptive capacity and community-based natural resource management," Environmental Management, vol. 35, no. 6, pp. 703-715, 2005.

[25] B. Thomas-Slayter, "A brief history of participatory methodologies," in Power, Process and Participation: Tools for Change, R. Slocum, L. Wichart, D. Rocheleau, and B. ThomasSlayter, Eds., pp. 9-17, Intermediate Technology Publications, London, UK, 1995.

[26] H. C. Goma, K. Rahim, G. Nagendo, J. Riley, and A. Stein, "Participatory studies for agroecosystems evaluation," Agriculture, Ecosystems and Environment, vol. 87, pp. 179-190, 2001.

[27] A. Agrawal, "Sustainable governance of common-pool resources: context, methods, and politics," Annual Review of Anthropology, vol. 32, pp. 243-262, 2003.

[28] C. Fabricius, E. Koch, H. Magome, and S. Turner, Rural Development Community-Based Natural Resources Management in Southern Africa, Earthscan Publishers, 2004.

[29] J. S. Gruber, "Key principles of community-based natural resource management: a synthesis and interpretation of identified effective approaches for managing the commons," Environmental Management, vol. 45, no. 1, pp. 52-66, 2010.

[30] R. Chambers, "The origins and practice of participatory rural appraisal," World Development, vol. 22, no. 7, pp. 953-969, 1994.

[31] N. Nemarundwe and M. Richards, "Participatory methods for exploring liveliho od values derived from forests: potentials and limitations," in Uncovering the Hidden Harvest. Valuation
Methods for Woodlands and Forest Resources, B. M. Campbell and M. K. Luckert, Eds., Earthscan Publication, London, UK, 2002.

[32] A. Agrawal and C. C. Gibson, "Enchantment and disenchantment: the role of community in natural resource conservation," World Development, vol. 27, no. 4, pp. 629-649, 1999.

[33] D. Rocheleau, "Maps as power tools: locating communities in space or situating people and ecologies in place?" in Communities and Conservation. History and Politics of CommunityBased Natural Resource Management, J. P. Brosius, A. L. Tsing, and C. Zerner, Eds., Altamira Press, Walnut Creek, Calif, USA, 2005.

[34] R. Slocum, L. Wichhart, D. Rocheleau, and B. ThomasSlayter, Eds., Power, process and participation: Tools for change, Intermediate Technology Publication, London, UK, 1995.

[35] P. L. Howard, Ed., Women and Plants. Gender Relations in Biodiversity Management and Conservation, Zed Books, New York, NY, USA, 2003.

[36] Ministry of Housing and Urban Development (MINHUD), "Population and Housing Census," Census Report, MINHUD, Yaounde, Cameroon, 2005.

[37] G. Hardin, "The tragedy of the commons," Science, vol. 162, no. 3859, pp. 1243-1248, 1968.

[38] F. Berkes, Local Level Management and the Commons Problem, Butterworth and Co, London, UK, 1986.

[39] E. Ostrom, Governing the Commons: The Evolution of Institutions for Collective Action, Cambridge University Press, Cambridge, UK, 1990.

[40] T. Hilhorst and N. Aarnik, Co-Managing the Commons. Setting the Stage in Mali and Zambia, Royal Tropical Institute, The Netherlands, 1999.

[41] World Resource Institute (WRI), The Wealth of the Poor. Managing Ecosystems to Fight Poverty, World Resource Institute, Washington, DC, USA, 2005.

[42] J. J. Faure, "Le Cameroun et ses forets lere partie: la cadre naturel," Revue Forestiere Francais, vol. 41, pp. 6-19, 1989.

[43] N. Njib, Rapport National sur le Secteur Forestier, ONADEF, Republique du Cameroun, 1999.

[44] B. A. Zanetell and B. A. Knuth, "Participation rhetoric or community-based management reality? Influences on willingness to participate in a Venezuelan freshwater fishery," World Development, vol. 32, no. 5, pp. 793-807, 2004.

[45] L. T. Soeftestad, Ed., "The Community-Based Natural Resource Management Network," Newsletter, Issues 1-25, 2006, http://www.cbnrm.net/index.html.

[46] P. Mbile, A. DeGrande, and D. Okon, "Integrating participatory resource mapping and geographic information systems in forest conservation and natural resources management in Cameroon: a methodological guide," The Electronic Journal on Information Systems in Developing Countries, vol. 14, no. 2, pp. $1-11,2003$.

[47] D. A. Messerschmidt, "Rapid appraisal for community forestry: RA process and rapid diagnostic tools," International Institution for Environment and Development, p. 136, 1995.

[48] R. Chambers, "Participatory mapping and geographic information systems: whose map? who is empowered and who disempowered? who gains and loses?" The Electronic Journal of Information Systems in Developing Countries, vol. 25, no. 2, pp. 1-11, 2006.

[49] K. Smith, C. B. Barrett, and P. W. Box, "Participatory risk mapping for targeting research and assistance: with an example from East African pastoralists," World Development, vol. 28, no. 11, pp. 1945-1959, 2000. 
[50] M. K. McCall, "Seeking good governance in participatory-GIS: a review of processes and governance dimensions in applying GIS to participatory spatial planning," Habitat International, vol. 27, no. 4, pp. 549-573, 2003.

[51] S. Duvail, O. Hamerlynck, R. X. Nandi, P. Mwambeso, and R. Elibariti, "Participatory mapping for local management of natural resources in villages of the Rufiji district (Tanzania)," The Electronic Journal of Information Systems in Developing Countries, vol. 25, no. 6, pp. 1-16, 2006.

[52] N. Ghogomo, "The geology of Cameroon: an update," in Readings in Geography, C. M. Lambi and B. E. Eze, Eds., Unique Printers, Bamenda, Cameroon, 2001.

[53] S. N. Ayonghe, G. T. Mafany, E. Ntasin, and P. Samalang, "Seismically activated swarm of landslides, tension cracks, and a rockfall after heavy rainfall in Bafaka, Cameroon," Natural Hazards, vol. 19, no. 1, pp. 13-27, 1999.

[54] B. D. Etongo, Land use dynamics and vegetation change in Ekondo-titi sub-region, Cameroon, M.S. thesis, Department of Geography, University of Buea, Cameroon, 2007.

[55] B. D. Etongo, Assessing the impact of agricultural practices on the forest ecosystem in Ekondo-titi sub-region of Cameroon, M.S. thesis, Department of Biology, Turku University, Turku, Finland, 2010.

[56] C. E. Campbell, "Some environmental effects of rural subdividing in an arid area: a case study in Arizona," The Journal of Geography, vol. 71, pp. 443-464, 1986.

[57] G. Dei, "The indigenous responses of a Ghanaian rural community to seasonal food supply cycles and the socioenvironmental stresses of the 1980s," in Development from Within: Survival in Rural Africa, D. R. Fraser and F. Makenzie, Eds., pp. 51-58, Routledge, New York, NY, USA, 1988.

[58] J. Falconer, "The major significance of minor forest products: the local use and value of forests in West African humid forest zone," Community Forestry Note 6, Rome, Italy, 1990.

[59] D. E. Rocheleau, "Gender, ecology, and the science of survival: stories and lessons from Kenya," Agriculture and Human Values, vol. 8, no. 1-2, pp. 156-165, 1991.

[60] G. N. Nabanoga and W. S. Gombya-Sembajjwe, "The effect of household endowments and entitlements on sustainability of natural forests," International Forestry Review, vol. 3, no. 1, pp. 34-41, 2001.

[61] H. Mogaka, S. Gacheke, J. Turpie, L. Emerton, and F. Karaja, "Economic aspects of community invovolvement in sustainable forest management in eastern and southern Africa, IUCN-Eastern Africa Regional Office," Forest and Social Perspectives in Conservation 8, Nairobi, Kenya, 2001.

[62] D. Kaimowitz, "Not by bread alone... forests and rural livelihood in sub-Saharan Africa," in Forests in Poverty Reduction Startegies: Capturing the Potentials. EFI Proceedings, T. Oksanen, B. Pajari, and T. Tuomasjukka, Eds., no. 47, pp. 63 44, 2003.

[63] FAO, "Integrated land use in forest reserves in the eastern region: global diagnosis and the involvement of people. Fuelwood Development for Energy in Sudan," Project GCP/SUD/033/NET Field Document No. 11, FAO, 1986.

[64] World Rainforest Movement (WRI), Cameroon: Oil Palm, People and the Environment. WRM Bulletin, no. 47, 2001.

[65] C. Padoch and A. P. Vayda, "Patterns of resource use and human settlement in tropical forests," in Tropical Rain Forest Ecosystems, Structure and Function, Ecosystems of the World, F. B. Golley and H. Leith, Eds., vol. 14, pp. 301-312, 1983.

[66] F. K. Wiersum, Developing strategies for social forestry: a conceptual approach. Working paper, Environment and Policy Institute, East-West Center, Honolulu, Hawai, 1984.
[67] M. Seniloli, L. Taylor, and S. Fulivial, "Gender issues in environmental sustainability and poverty reduction in the community: social and community issues," Development Bulletin, vol. 58, pp. 96-98, 2002.

[68] G. Borrini-Feyerabend, Collaborative Management of Protected Areas: Tailoring the Approach to the Context, IUCN, Gland, Switzerland, 1996. 

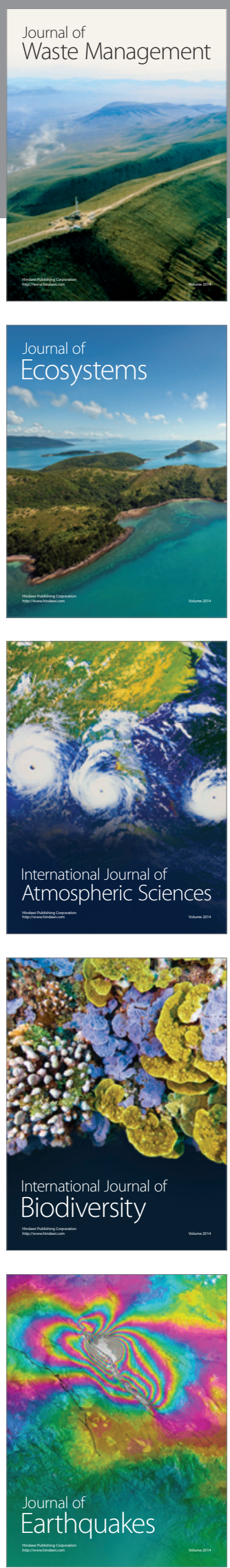
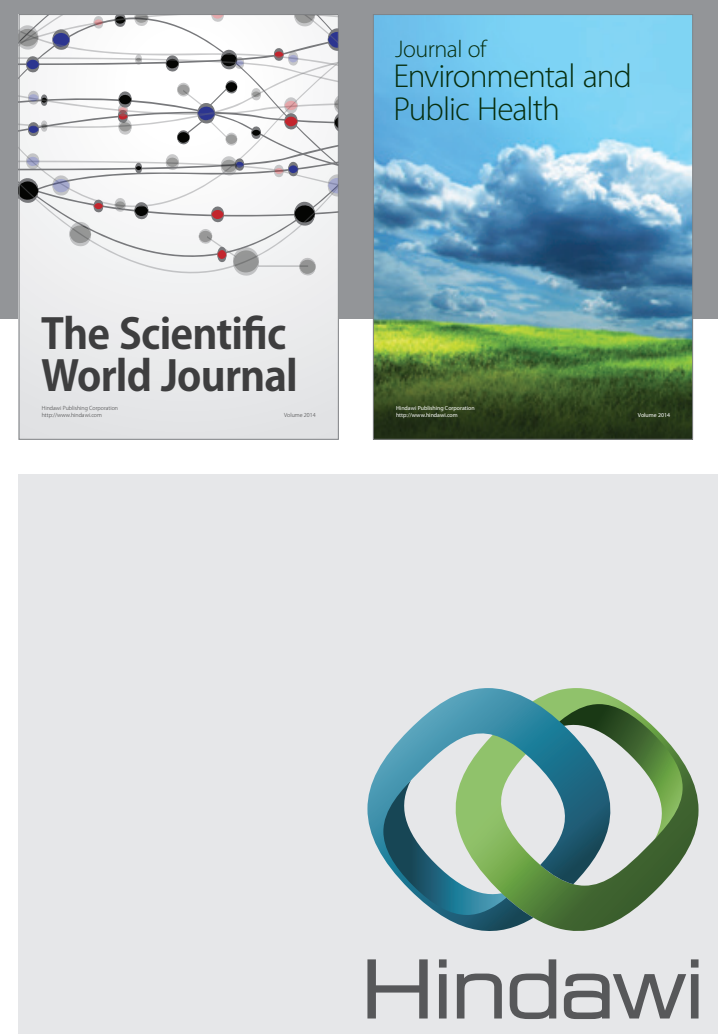

Submit your manuscripts at

http://www.hindawi.com
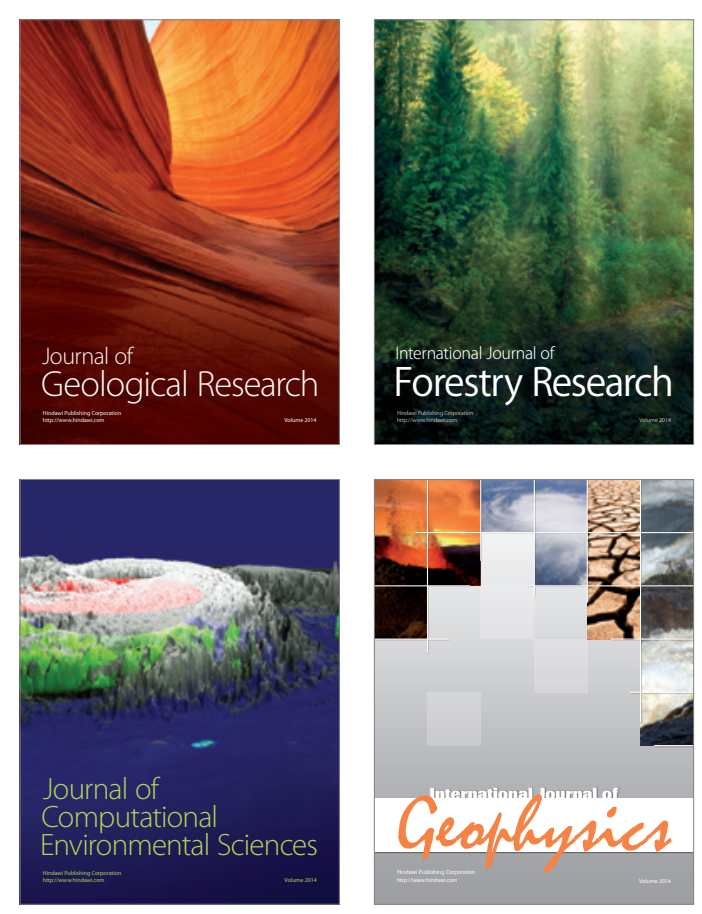
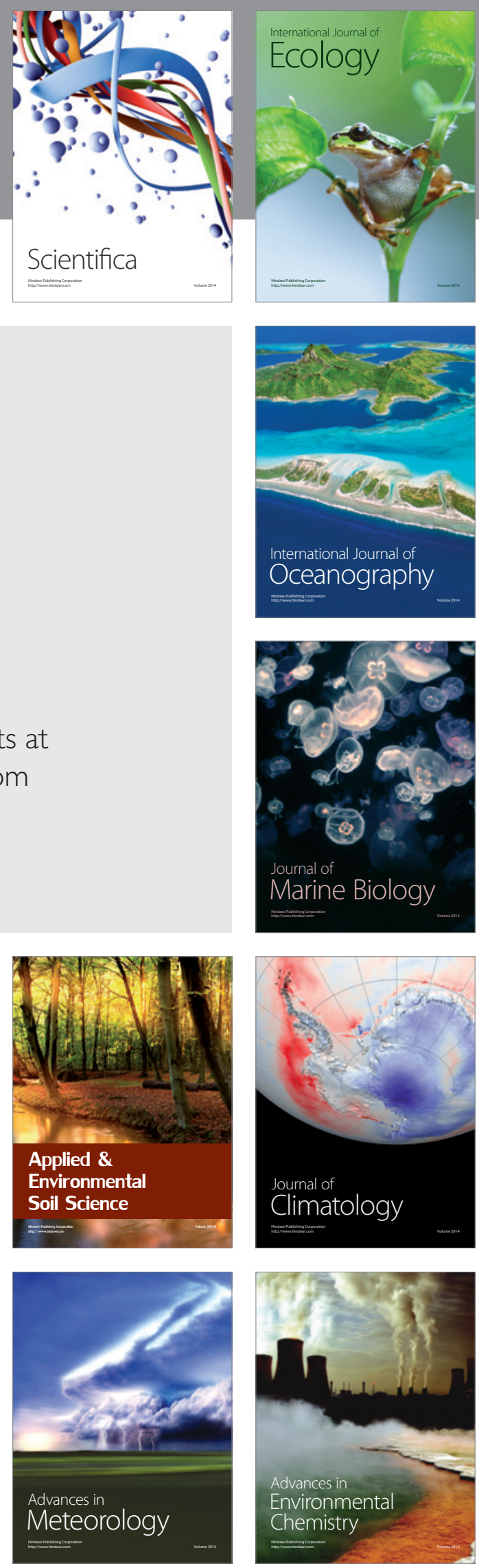